\title{
Theoretical response of small-scale wind turbines to the wind regimes of mesoregion Fronteira Sul, Brazil
}

\author{
D.D. Fabiane, R. Treméa, J.M.V. Grzybowski \\ Universidade Federal da Fronteira Sul - UFFS \\ Av. Dom João Hoffmann, 313, CEP 99.700-000, Erechim, RS. \\ E-mail: jose.grzybowski@uffs.edu.br
}

\begin{abstract}
On the basis of the wind regime in 16 sites of mesoregion Fronteira Sul and the output power curves of real wind generators, the response of small-scale wind turbines is accessed in terms of average output power and energy production during a year, from Summer (2011/2012) to Spring (2012). We consider five wind generators currently available for purchase and determine their performances in each of the sites by using real data and real power curves.
\end{abstract}

\section{Introduction}

As properly exploited, wind power can supply a substantial share of the actual load demand of electricity [1][2]. The attractiveness of wind power lies upon zero emission, abundant wind availability, low operational cost and scalability, among others, being suitable for applications ranging from extensive wind farms to residential standalone wind generators. While prospective studies concerning wind power potential usually focus on extensive projects such as wind farms, an alternative direction that considers recent technological advances in the design of small-scale wind generators has pointed towards the importance of microgeneration to reduce the system's dependence upon base load, thus weaving a increasingly decentralized electrical grid [2]. Towards this end, a crucial requirement is the existence of practical data regarding wind energy potential in terms of existing wind regimes and turbines, thus showing how attractive wind energy looks like in a given location. In this research, we investigate and estimate the energy outputs of 5 small-scale wind turbines to a combination of 16 locations within mesoregion Fronteira Sul and its surroundings. The study comprises one year of data, from Summer (2011/2012) to Spring (2012). The results estimate that a small-scale wind turbine could produce up to $6,000 \mathrm{kWh}$ of annual output, which corresponds to the annual consumption of up to five average Brazilian households.

\section{Materials and methods}

The wind velocity data were collected by meteorological stations of INMET (Instituto Nacional de Meteorologia) and they consist of mean velocities of samples obtained by measuring wind velocity for 10 minutes during every hour at the height $h=10$ meters. The data used in this study corresponds to the summer (2011/2012), autumn, winter and spring (2012). For each season, and site, the original wind data from 10 meters, $v_{10}$, were extrapolated to the height $h$ of were extrapolated to the height $h=12$ by means of the theoretical-empirical equation

$$
v_{h}=v_{10}\left(0,234+0,656 \log _{10}(h+4,75)\right)
$$

such that $v_{h}$ is the estimated velocity at height $h$ [4], which corresponds to a reasonable height of the hub for a small-scale wind turbine. The wind velocity data were separated into $N$ bins of width $w_{j}$ and midpoints $m_{j}$. The frequency, i.e., the number of occurrences in each bin, is denoted $f_{j}$ and the number of wind velocity readings equals

$$
n=\sum_{j=1}^{N} f_{j}
$$

The long-term average wind power per square meter (in $\mathrm{W} / \mathrm{m}^{2}$ ) is given by

$$
\bar{P}=\frac{1}{2 n} \rho \sum_{j=1}^{N} m_{j}^{3} f_{j}
$$


where $\rho$ is the density of air [5]. Note that equation (3) represents the average power available in the moving mass of air per unit area. From the Betz limit [5], recall that the theoretical limit of extractable power from the wind is $16 / 27$ of the total available power, which yields

$$
\bar{P}=\frac{16}{54 n} \rho \sum_{j=1}^{N} m_{j}^{3} f_{j}
$$

As a given generator has a output power function $P_{w}(v)$, the average wind machine power is

$$
P_{\bar{w}}(v)=\frac{1}{n} \sum_{j=1}^{N} P_{w}\left(m_{j}\right) f_{j}
$$

The estimation of the total energy output is obtained by simple multiplication of the average wind power, in equation (5), by the number of hours in a season (for seasonal energy output). Characteristically, the output power curve of wind generators has a sigmoid-shaped evolution as wind velocity increases from zero. To model such behavior, the general function

$$
P(v)=\frac{A}{B+C e^{-D v}}
$$

was employed, whose parameters $A, B, C, D$ are estimated for the output power curve of each generator by means of the Levemberg-Marquardt algorithm. The generators considered in the study and some of their characteristics, as they read in their respective operation's manuals [6][7][8][9], are presented in the table below.

\begin{tabular}{|l|r|r|r|r|}
\hline \multicolumn{1}{|c|}{ Generator } & Diameter $(\mathbf{m})$ & Cut-in(m/s) & Cut-out $(\mathbf{m} / \mathbf{s})$ & \multicolumn{1}{c|}{ Rated power (kW) } \\
\hline Verne 555 & 5.55 & 2.2 & 16.0 & 6.0 \\
\hline XZeres110 & 3.60 & 2.5 & 16.0 & 2.5 \\
\hline Bergey Excel 5 & 6.20 & 2.0 & - & 6.2 \\
\hline XZeres442SR & 7.20 & 2.2 & - & 10.0 \\
\hline Bergey Excel 10 & 7.00 & 2.2 & - & 10.0 \\
\hline
\end{tabular}

\section{Results}

All five generators were found to provide largest outputs during the Spring wind regime, then Winter and Summer. The largest output was found to be that of XZeres 442SR, followed by Bergey Excel 10, Bergey Excel 5, Verne 555 and XZeres 110. Such ordering agrees with that of the rotor diameters, from the largest to the smallest, which conveys that each generator would respond accordingly to its size and give a fair response to the wind velocity ranges and frequencies. Otherwise orderings could indicate inadequacy of the generator's characteristics to the wind regimes, such as too high cut-in velocity.

Annual energy output (kWh)

$\begin{array}{lrrrrr}\text { Clevelândia } & 806.7 & 407.4 & 1,093.0 & 1,590.2 & 1,083.2 \\ \text { Cruz Alta } & 3,150.0 & 1,622.6 & 4,162.5 & 6,221.4 & 4,398.5 \\ \text { Dionísio Cerqueira } & 2,112.9 & 1,121.0 & 2,792.7 & 4,230.5 & 2,942.6 \\ \text { Dois Vizinhos } & 1,169.5 & 555.5 & 1,575.5 & 2,236.5 & 1,589.7 \\ \text { Erechim } & 784.5 & 321.7 & 1,122.8 & 1,434.1 & 963.2 \\ \text { Foz do Iguaçu } & 1,485.7 & 727.2 & 2,018.9 & 2,896.3 & 2,010.8 \\ \text { Frederico Westphalen } & 891.2 & 396.6 & 1,248.8 & 1,676.2 & 1,135.3 \\ \text { Novo Horizonte } & 2,097.5 & 1,046.4 & 2,838.6 & 4,125.7 & 2,870.4 \\ \text { Palmeira das Missões } & 1,728.0 & 827.2 & 2,370.1 & 3,335.1 & 2,278.5 \\ \text { Passo Fundo } & 2,109.9 & 1,040.7 & 2,854.6 & 4,113.5 & 2,844.9 \\ \text { Planalto } & 1,885.2 & 890.5 & 2,580.7 & 3,614.7 & 2,495.4 \\ \text { Santa Rosa } & 557.8 & 242.2 & 782.2 & 1,038.0 & 710.0 \\ \text { Santo Augusto } & 1,316.2 & 599.8 & 1,835.4 & 2,505.8 & 1,712.1 \\ \text { São Luiz Gonzaga } & 1,305.7 & 566.6 & 1,847.4 & 2,438.2 & 1,636.7 \\ \text { São Miguel do Oeste } & 1,571.1 & 723.5 & 2,165.9 & 2,984.1 & 2,056.9 \\ \text { Xanxerê } & 2,833.0 & 1,464.4 & 3,737.9 & 5,599.4 & 3,962.6\end{array}$


The performance of each generator is presented in the table above. Most windy sites within the region, such as Cruz Alta, Dionísio Cerqueira, Novo Horizonte, Passo Fundo and Xanxerê, were found to provide estimated annual energy outputs ranging between 4,000 to 6,000 $\mathrm{kWh}$ for XZeres 442SR, which corresponds to the annual demand of 5 households with average monthly consumption of about 80 to $100 \mathrm{kWh}$. The results are hoped to be useful and support preliminary discussions concerning the viability of small-scale wind generator projects within the mesoregion Fronteira Sul. As the output power curves considered in this paper are those provided by the manufacturers, they shall be subject to confirmation by third parties for accuracy.

The authors thank CNPq for the support.

Keywords: Weibull distribution. output power. wind energy production. small-scale wind generators. Fronteira Sul.

\section{References}

[1] X. Lu. M.B. McElroy. J. Kiviluoma. Global potential for wind-generated electricity. Proc. National Academy of Science. vol. 106. number 27. pages 10933-10938. (2009).

[2] M.Z. Jacobson. M.A. Delucchi. A path to sustainable energy by 2030. Scientific American. November. pages 58-65. (2009).

[3] C.L. Archer. M.Z. Jacobson. Spatial and temporal distributions of the US winds and wind power at 80m derived from measurements. J. Geophys. Research. vol. 108. issue D9. (2003).

[4] E.P. da Silva. Energia eólica: considerações teóricas e aplicação prática. Revista Tecnologia. number 13. (1992).

[5] J.F. Manwell. J.G. McGowan. A.L. Rogers. Wind energy explained - theory, design and application. John Wiley \& Sons. 2002.

[6] XZeres Machines Brochure. Available in http://energysmartcompany.com/files/media/xzereswind-turbines/1429-XZERES-Brochure-6-21-2011-Low.pdf.

[7] Aerogerador Verne555: Manual do produto. Available in www.enersud.com.br/wpcontent/.../manual_produtos_verne555_web.pdf. Access in June. 06th. 2013.

[8] Bergey Excel 5 Brochure. Available in http://bergey.com/documents/2012/05/excel-5-specsheet.pdf.

[9] Bergey Excel 10 Brochure. Available in http://bergey.com/documents/2012/05/excel-10brochure.pdf. 